\title{
Growth of private medicine in Sweden: The new diversity and the new challenge
}

\author{
Marilynn M. Rosenthal \\ Program in Health Policy Studies, University of Michigan, Dearborm, \\ Michigan, U.S.A.
}

Accepted 27 November 1991

\section{Summary}

The growth of private medical care in Sweden has occurred desplte the lack of overt encouragement by the long-term Social Democrat government. This can be documented from official govemment statistics, private insurance sales, modia sources, membership growth in the private doctors association, purchase of private risk insurance, growth of private health care organizations and services, and particularly an increase in public sector private contracting. While the percent of the population with private insurance is close to $1 \%$, it is probable that over $20 \%$ of physicians engage in some form of private practice. Explanations range from increasing criticiam of poor service orientation in the public system, long waiting lists and the reduced rate of public spending, to a general atmosphere that asserts more Individual cholce. Wh the social Democrats now out of power, it is llkely that the Moderate coalition will oficially promote some forms of privatization. What will be the impact on the long-cherished Swodish principle of equity?

Sweden; Private medical care

\section{Introduction}

In the late 1980s, two articles appeared in American scholarly journals discussing the growth of private medical care in Sweden [1,2]. This

Revised version of a paper presented at the Conference: 'Swedish Health Pollcy - A Comparative Perspective \& Foreign Observers' Vlews' held in Högberga, Lidingo, Sweden on August 22-24, 1990.

Address for correspondence: Prof. Marlynn Rosentha, Director, Program in Health Policy Studies, University of Michigan, Dearborn, MI 48104, U.S.A. 
development was surprising on ideological grounds since the Social Democrats, with a strong commitment to equity, class solidarity and the Welfare State, have dominated Swedish politics and government for more than 50 years. And the public health care system has been the litchpin, the 'heart', of social welfare policy.

These two articles documented the changes in a variety of ways, offered a number of explanations, and discussed an array of official reactions, taken or predicted. This is an excellent opportunity, 5 years after the last data collected in those articles, to update the documentation, and review the analysis and discussion.

\section{Indications of growth}

Documentation was offered that included types of private practitioners (full-time, part-time and spare-time), markets for private health insurance (both group and individual), the growth of new delivery facilities and programs, and the growth of private practice risk insurance. These categories are, of course, often overlapping and interlocking in various ways. One article also provided documentation on the 'shortplus' of physicians, their reduced working time, increased time off and financial incentives to engage in private practice [2]. While specific figures were not available, there was also evidence of private practice entirely outside the social insurance structure. What new documentation may be added to some of these categories today?

\section{Private practitioners and private contracting}

Both the Landstingforbundet [3] and the Riksforsakringsverket [4] provide a clear picture of the activities of physicians who have contracts through the social insurance as full-time or part-time private practitioners, as well as those with Dagmar spare-time contracts through the Counties.

After an initial steep post-Dagmar decline in 1985, total private visits have increased between $4 \%$ and 7.4\% 1986-1989. Laboratory work by private doctors, in that same period of time, increased between $12 \%$ and $26.8 \%$. The number of full-time doctors affiliated with the social insurance has actually reached a figure (845) greater than that in 1975 when it was 807 , although this, of course, must be understood as a proportion of the entire doctor pool. Total money spent on this form of private care has probably now reached 1 billion kroner [4].

However, informed opinions on private contracts for spare-time private practice suggest that the number of visits to these doctors has declined as was the intent of the Dagmar reform. In fact, while there has been a small increase in the number of full-time practitioners by $20-30$ in the last several years [5], the counties have used their new powers under Dagmar to reduce the number of spare-time contracts to individual practitioners. 
Table 1

Number of private doctor vistis (1009s) within the Soclal Haath Insurance and Private Controting with County Counclis, 1984-1988

\begin{tabular}{lcrrrr}
\hline & 1984 & 1985 & 1986 & 1987 & 1988 \\
\hline Social insurance private care & 3384 & 2782 & 2947 & 3124 & 3373 \\
Private contracts with counties & - & 613 & 644 & 706 & 656 \\
Total & 3384 & 3395 & 3591 & 3830 & 4029 \\
\hline
\end{tabular}

Sources: Calltorp and Rosenthal, Nordisk Medicin 105 (8-9/1990) 231.

In their place, they have substituted the increasing practice of private contracting of a varying nature. This is an important trend that has developed since 1985. The counties, following the suggestions of the Federation of County Councils, have offered short-term private contracts to both their own county-employed physicians, a variety of individual health practitioners, private medical groups and other medical enterprises and businesses [3]. The emphasis has very much been on group contracts. In effect, this substitutes county-controlled, short-term private work related to county-determined needs and priorities for private initiatives determined by individual doctors and individual patient choice (see Table 1).

One particularly striking use of private contracting has been noted by Calltorp [6]. He documents that $25 \%$ of coronary bypass surgery in 1988 was performed in the private sector via county contracting. This does suggest a significant inability to organize public sector facilities for an important medical need.

However, the amount of private contracting varies significantly from year to year. While 1987 saw a high point in contracts, there was a decline in 1988 [3]. 1990 has produced a much lower number of contracts, at least in Stockholm County [7]. The meaning of these alternating patterns is not clear.

The counties continue their long-established practice of buying a variety of other services in the private sector. These include nursing home beds, diagnostic and laboratory services and private management.

There are a variety of ways to look at the Swedish physician manpower pool and its employment patterns. The Statistisk Arsbok for Landsting and SPRI provide trend data for 1975-1987 [8].

If we use a variety of figures that are available for 1987, there were 25000 doctors in Sweden and 19500 of them were employed by the counties. Of these, about 12450 are fully-trained, with another 6700 in various training stages, for a total of about $78 \%$. The rest are in other public employ: schools, the military, in government departments as occupational health doctors; or, in the private sector: company doctors, in the pharmaceutical industry, the insurance industry, out of the country, private with the social insurance, private outside the social insurance. 
The term 'private care' has invariably been defined as those offering private care through the social insurance system. This is a limited definition. The private sector is a mix of doctors in various solo and group practices inside and outside the social insurance and those working for companies of various sorts in the private sector. One set of figures, from the Swedish Medical Association Research Department, lists 1200 doctors working for private companies, 100 working for the pharmaceutical industry, 1000 in full-time private practice and 1000 part-time [8].

Still difficult to document is the growth of private medical practice entirely outside the social insurance and contract system where people are paying for care either out-of-pocket or through private group or individual health insurance. One knowledgeable estimate is that there may be 200-300 doctors in Sweden outside the social insurance system [7]. This may be underestimated. One may try to gauge the dimensions of entirely private practice in a variety of ways: the growth of the Private Doctors Association, the listing of two categories of private doctors in a Stockholm directory published annually by SPLF (The Private Doctors Association), the numbers of doctors continuing to purchase private practice risk insurance.

To qualify for membership in SPLF, one must be 'almost exclusively a private doctor', but not necessarily full-time. In 1986, the membership was 1401 ; in 1990 , it was 1573 , an $11 \%$ increase. The majority of the new members are younger doctors. It is estimated that $90 \%$ of private doctors belong.

The Lakarforbund's local Stockholm chapter publishes an annual directory of private doctors and dentists in Stockholm (in other geographic locations, as well) which one may obtain in the Apotek, among other places [9]. Doctors pay to have their names included in this directory. In the 1990 edition, 560 doctors are listed, 131 of them without an (F) after their names, signifying that they do not have social insurance contracts. This is $22.9 \%$ of Stockholm County private doctors. Some of these may be practitioners with 'spare-time' contracts, however, as suggested by Mosten (see Notes).

SPLF suggests that interest in private practice is growing because doctors in the county system have too many administrative responsibilities and not enough time with patients, that the system has become too bureaucratic and that 'nobody cares what they are doing'. Added to this is a more positive change in the general societal attitude towards private sector activity. Furthermore, Mosten points out that the younger doctors who purchase private contracts from retiring doctors (and for which they pay increasing prices) tend to work more (see Notes).

The 60th anniversary booklet of SPLF includes a letter of congratulations from Prime Minister Ingvar Carlsson. In it, the Prime Minister says, among other things, that the private sector is a 'valuable complement' to the public sector.

An additional comment should be made about the recent round of negotiations between SPLF and the government about the tariffs for private doctors. They are described as particularly agreeable and successful, with the 
Table 2

Swedish doctors with private prectice risk insurance

\begin{tabular}{lllll}
\hline \multicolumn{5}{l}{ Part-time private practice risk insurance } \\
\cline { 2 - 5 } 1983 & 1984 & 1985 & 1990 \\
\hline 3304 & 3409 & 3917 & 4296 \\
\hline & \multicolumn{4}{l}{ Full-time private practice risk insurance } \\
\cline { 2 - 4 } & 1983 & 1984 & 1985 & 1990 \\
\hline 654 & 672 & 1161 & 1541 \\
Total & 3958 & 4081 & 5078 & 5837 \\
\hline
\end{tabular}

Source: Rosenthal [1]; Salus, private correspondence, June 1990.

best negotiating relations in recent memory. They produced favorable changes in the tariffs that are encouraging to the private doctors [7].

\section{Private practice risk insurance}

Since the figures published in the 1986 article, the purchase of private risk insurance from Salus (which claims $90 \%$ of the market) has grown considerably, particularly in the 'full-time' category. In 1985, 1161 doctors had this full-time insurance. In 1990, 1541 had the insurance. That is an increase of $24 \%$. The increase in part-time insurance is much smaller during this same period [10] (see Table 2).

What is documentable is that, in 1989-1990, 847 full-time private doctors collected social insurance fees; SPLF had 1573 members; 1541 doctors purchased full-time private risk insurance. It is known that a certain number of SPLF members are older, with limited practices. But $1541-847=694$. It should be assumed that not all with the risk insurance are actually practicing. But what number are? Probably considerably more than the 200-300 estimate.

Calculations of the number of Swedish doctors in some sort of private practice must remain tentative. Although a variety of sources are cited in this paper, some figures may represent 'double' counting.

\section{The private health insurance market}

In 1986, the two large insurance companies, Skandia and TryggHansa, were selling both group and individual health insurance. 5500 individuals were covered by June of that year, primarily through group insurance that has been surprisingly attractive to small and medium-sized companies rather than the large corporations originally targeted.

Those two companies had projected markets of 5000 and 3500 , respectively. 
Table 3

Swedlsh private haalth insurance Industry: numbers of Individuals covered, 1974-1990

\begin{tabular}{llll}
\hline Company & 1974 & 1986 & 1990 \\
\hline Skandia & $25-30$ & 4500 & 15000 \\
TryggHansa & & 1000 & $5-6000$ \\
Wasa & & 23800 \\
& & & 1680 (in group policies) \\
\hline
\end{tabular}

Sources: see References 11, 12 and 13.

It has been estimated by a knowledgeable source that three years ago in 1988, three of the large insurance companies probably had sold 5000 policies each [7].

However, today, we can look at just one of these companies, Skandia, to see the growth that has taken place [11]. This company, which dominates the private health insurance market, has itself seen a 300\% growth in the individuals covered in its group policies since 1985, from 5000 to 15000 . Before 1985, they covered most of the large corporations' health policies for senior executives. The growth since then has been almost exclusively among $1-$ 3 person small businesses. TryggHansa reports entering the market in 1985 and having now reached 5000-6000 individual policies, many of which are sold through private companies that then pick up the tax tab [12] (see Table 3). Mosten notes that the Wasa Insurance Company is offering a particularly lowpriced health insurance product, in anticipation of a mass market developing [12] (see Notes).

It has been suggested that one gauge of the interest in private health insurance might be the interest in private pension insurance. In 1986, that was $12 \%$ of the Swedish population; the market today is estimated at $24 \%$ [13]. The difference between the two markets, of course, is that there are tax deductions for private pensions, but not for private health insurance where there are taxes to be paid for such insurance policies.

\section{Private facilities}

The documentation on the growth of private facilities between 1974 and 1984 was impressive but, of necessity, incomplete. Dominating this market is the long-established, doctor-owned Praktikertjanst, which has about $50 \%$ of the market for private care, as it is variously defined. The rest of the market is split between a growing number of diverse enterprises. One may get a sense of growth since 1985 by examining Praktikertjanst's annual reports and records [5].

The company offers a wide variety of doctor, dentist, hospital, primary care, physiotherapist, psychological and specialized services and facilities. Its doctors have a certain proportion of social insurance contracts. It receives a number of the new private contracts from the counties. The company can 
document a growth of personnel of almost 14\%; an increase in almost all categories of activity in a 25-year period and (since the information in the 1986 article) a wide array of enterprises planned for the 1990s. Plans and cooperative ventures both with the counties and with various private sector organizations are extensive.

What of the other private enterprises? It is estimated that there may be 1015 small organizations trying to imitate Praktikertjanst [7]. However, their stability and longevity are uncertain.

\section{An advertising explosion}

In 1986, 'Svenska Dagbladet' (SD), an important national newspaper, started a new regular Monday section called 'Experthjalp'. It is devoted overwhelmingly to medical services. It has been phenomenally successful, with the number of ads increasing $500 \%$ in one year [14]. Dagens Nyheter followed suit in Spring, 1990. The weekly SD page is a melange of advertisements by doctors, other health practitioners, group practices, clinics, hospitals and specialty services. While most are located in Stockholm, Malmo and Gothenberg, ads from Uppsala, Falun, Orebro, Umea, Helsingborg, Landskrona and Falkoping, to list a recent week's ads, are also found (April 9, 1990) [14].

The list of groups, facilities and packages include new names compared to 1986 information: Svea Clinic, Europa Clinic, Cura-clinic, Elisabeth Hospital, Medocular, Sergel Kliniken, Mediservice Optagon, City Kliniken, Drottning Kliniken, and Linne Halsocenter, as well as the familiar HumanaCare. A certain number of the ads are for plastic surgery, usually not covered in the public sector, but these are by no means the majority. Noteworthy is the fact that many of the ads are for people offering specialty services rather than general practice, which was the profile of private doctors in earlier decades.

While one is not able to assess the breadth, stability, quality and success of these groups, the existence of these new advertisements suggests a growing market for private care.

Another mass media phenomenon is extensive press coverage and discussion of private medicine developments $[14,15]$. While such articles do not provide an objective picture of the extent of private care, they do reflect and stimulate public interest.

\section{Other activitles}

Several additional trends are notable, particularly the private use of private contracting. It appears that private corporations and interest groups may wish to expand their health-related activities. These often emphasize wellness checkups. But the new tax law, which makes companies responsible for paying the first 2 weeks of sick leave, will certainly stimulate interest in rapid access to health care, as well as preventive services. Furthermore, the new law 
mandating rehabilitation programs for workers with more than $\mathbf{3 0}$ days sick leave a year will increase the demand for rehab facilities and programs. And the explosive growth of the 'oldest old' in the population (by the Year 2000: over $80=26 \%$ growth; over $85=55 \%$ ) will bring great demand for a variety of health and health-related services.

Of course, public monies will purchase a good deal of this, but the private opportunities are great. It is unlikely that the public system will be able to afford the implied demand within the current constraints of public finances.

It should also be noted that private health contracting is a major international trend, taking a variety of forms in different countries. It allows for the provision of services without the contracting organizations making a long-term investment in personnel and facilities.

\section{Why is the private medical sector growing?}

The earlier articles suggested and documented five precipitating factors: (1) diminishing rate of public health care spending; (2) growing criticism of the public health care, particularly the waiting times and the poor service orientation; (3) increased public interest in freedom of choice; (4) growing numbers of doctors with the time and financial motivation to engage in private practice; and (5) growing numbers of the population with the money for private care.

None of these precipitating factors has gone away in the last 5 years. Indeed, they are only more extensively documented. (They have been noted by foreign observers as well; for a very recent example, see Ham, 1990.) [15]

\section{Financial constraints}

The need for government on both the national and county levels to reduce spending and increase efficiency and productivity is widely discussed and known. The reduction in public spending on all levels is seen when figures from 1981-1983 are compared with 1987 [8]. The percent of GDP spent on health care has gone from a high of $9.7 \%$ in 1982 to $9.1 \%$ in 1987 [16].

The lively discussion in the Swedish press [17] about the state of the Swedish Welfare State has even been reflected in the Washington Post ('Running Out of Gas. As a Model, Sweden May Have Exhausted Itself') and the International Herald Tribune ("The "Swedish Model" is Still Alive') [18]. What is clear is that public spending has and must be reduced and greater efficiency in the public sector produced. The Minister of Finance is quoted as saying that productivity in the country in general has been going down $3 \%$ a year. The articles also highlight the debates about how this is to be accomplished, reflecting divisions within the Social Democratic Party, as well as differences between the political parties.

Hugh Heclo's Policy and Politics in Sweden [19] provides a vigorous analysis 
of Social Democrat policy evolution and internal discussions and divisions. This is useful background to the issues in health policy. They revolve, to a considerable degree, around the extent to which private markets should be encouraged and the struggle to maintain a 'collectivist democracy'.

The rate of growth of the health care budget, nationally, actually fluctuated considerably between 1980 and 1990, ranging between over three to under $1 \%$ [20]. There certainly has not been a steady reduction in rate of growth. Yet, the public perception is of a troubled health care system with long waiting times and lists, poor service orientation and reduction of services [21]. Much more sophisticated analysis has documented the tough decision-making and prioritizing that has gone on in the health care system [6]. Belief in the quality of care appears to remain high.

\section{Public opinion polls}

In addition to the surveys quoted in the previous articles, useful trend data are found in the 1988 Landstingsforbundet and Statistiska Centralbyran opinion poll report, 'Nyfiken? Halso-och sjukvarden far ros och ris av allmanheten' [22]. The percentages really can be read in a variety of ways, but less than half the respondents rate the medical and nursing care as excellent, with some decline in the latter over a 7-year period. More troublesome responses are found on page 6 where it is clear that the younger population is considerably more critical than the older, and that the overall evaluation has declined in the period reviewed. Yet, an overwhelmingly majority of respondents increasingly say that public monies for health care should not be reduced.

\section{Individual freedom and choice}

There is nothing to indicate a reduced interest in more individual choice. The physician pool continues to grow, as does the free time of the doctors. And, as for the affluence of the Swedish population, the big change is the new tax code which reduces taxes on the individual. It is hoped this will encourage more productivity in the work place. It will also produce more personal income which can be spent in a discretionary manner. This could include private health insurance.

\section{Discussion: drift without ideological drive}

Sweden is experiencing a drift towards private medical care that is not (yet) being driven by ideology. It is being driven by a non-use of ideology. The unavoidable comparison is with Britain, under a Conservative government that is dedicated to the private market as a solution to all economic woes.

Swedish health and medical care delivery is experiencing a new diversity. 
New for Sweden, but reflecting now familiar international trends. As in the West, Swedish health care must address, rigorously, cost containment measures. It must also face the economic need to shrink the size of government and the public sector. As in the East, there is growing skepticism about public service monopolies and large-scale planning. There is the suspicion, as many analysts suggest, beginning with the French sociologist Michels [23] that such monopolies are often planned more with the needs of the rationalizers and the providers in mind, than the consumers who pay for it all.

Heclo has also observed that "spontaneity and self-determination... become increasingly valued in mature and heavily-managed welfare states' [19]. People want more and more to make their own choices.

It was suggested in the original articles that the Social Democrat government would respond with co-optation, cooperation, competition and constraint. It would try to co-opt the desire for individual freedom, as it has with the concept of individual freedom within the public sector. This does not seem to have captured the public imagination, nor is individual patient choice rampant in the public health care delivery system. Cooperation with the private sector is an old county habit. It has grown with the use of private contracting, a successful manifestation of 'Dagmar', giving the counties better control over their own resources.

As for the assertion that the existence of a private sector provides useful competition for the public health care system, this is a misunderstanding of competition. Only when the internal incentive structure in the public health care sector is changed so that providers feel a sense of ownership and reward, will competition with the private sector perhaps be meaningful.

The Social Democrats' '90-Tals Programmet' (Planning Document for the 1990s) [20] calls for a renewal of the public sector, retaining public financing of care, but generating more public sector efficiency by minicing selected market mechanisms. The hope is to do this by creating 'internal markets', making the primary care units purchasers of care and the hospitals suppliers. This latter idea has been explored and explained by Saltman and von Otter [25]. Three different counties have established demonstration projects: Dalarna, Bohuslandstinget and Vastmanland. The one most touted and most imitated around the counties is the 'Dalamodellen', which resembles one of the many varieties of American HMOs. In the inevitable political use of semantics, the 'Dalamodellen' claims to increase individual choice. An examination of its details suggests quite the opposite. '90-Tals Programmet' makes no other mention of private markets.

Finally, constraint; that is, trying to constrain the totally private market. This continues. As yet, there are no overt, official public acts encouraging private health care. There have been, however, quiet signals (the increased purchasing of county private contracting; the Carlsson letter; the tone of the recent insurance tariff negotiations). Specifically, there are no tax breaks for private health insurance. Rather, there are a plethora of pragmatic 
opportunities for private health and medical care to continue to grow, and the general atmosphere has changed as already described. The Landstingforbundet's future planning project, 'Vagval', lays out three possible models for the Swedish health care system [26]: (1) continuation of the traditional system; (2) an independent primary care sector, purchasing care (internal markets); and (3) a universal national insurance system based on the West German model. Another alternative is one discussed by Ake Blomqvist [27] discussing the possibility of individual choice in alternate insurance arrangements.

What is clearly happening is that the present trends have outstripped the future planning, with a number of counter-currents occurring all at the same time. While private medical care is a small sector, it is growing at a vigorous rate.

Finn Diderichsen (see Notes) raises two useful questions about the growth of private medicine in Sweden. Is private medicine part of the problem or part of the solution? Will private medicine increase public efficiency or challenge equity? The answer to the first question depends on political ideology and the Fall, 1990 election results. The Social Democrats lost that election, and a Moderate coalition will now govern the country. They have already declared an interest in some forms of privatization and a desire to reduce the role of central government. By the same token, they have shared the Social Democrat commitment to principles of equity.

As for Diderichsen's second question, this author suggests the following observation: One certainly should continue to be positive and optimistic about the ability of Sweden to rise to the challenges confronting this trend in creative, realistic and fair-minded ways; to maintain its dedicated, admirable idealism and balance that with the desirability of more individual choice. Quoting from an earlier article (with one slight change):

The way in which Sweden responds to the growth of an indigenous private health care market will be a crucial example of whether a health care system can maintain equity in the face of increasing economic constraint and the need to reduce public sector spending.'[1].

To paraphrase the title of a book I have long admired: 'Can There be Equity and Diversity?'

\section{Notes}

A special thanks to Margareta Bowallius for her invaluable research assistance. The author also expresses appreciation to Finn Diderichsen and Karl-Evert Mosten, discussants for this paper at the August, 1990 conference on 'Swedish Health Policy-A Comparative Perspective: Foreign Observers' Views'. All of their comments were cogent, informed and helpful; some have been incorporated into this paper, and this is indicated by the designation 'see Notes'. 


\section{References}

1 Rosenthal, M.M., Beyond equity: Swedish health policy and the private sector, Milbank Quarterly, 64 (1986) 592-621.

2 Rosenthal, M.M., Physician surplus and the growth of private practice: The Case of Sweden, Scandinavian Studies, 61 (Spring-Summer 1989) 169-184.

3 Landstingsforbundet D-Cirkular D 90:16, Stockholm, Sweden, 1990-02-08.

4 Riksforsakringsverket Informerar, Privatlakarvard T O M 1989, Statistisk Rapport Is-R 1990:2, Stockholm, Sweden, pp. 2, 4, 7, 9.

5 Praktikertjanst Annual Report and Brochures, 1989; Interview, Karl-Evert Mosten, 19 June 1990.

6 Calltorp, J., Prioritering och Beslutsprocess I Sjukvardsfragor, Uppsala, 1989.

7 Sveriges Praktiserande Lakares Forening, 60th Anniversary Edition, Verksamheten 1986-87, 1988-89, 1989-90; Interview, 19 July 1990, Stockholm, Sweden.

8 Landstingsforbundet, Statistisk Arsbok for Landsting, 1989-90.

Swedish Medical Association, correspondence, .Kerstin Johanssen, Research Department, August 1990.

9 Lakarforbund, Lakare Tandlakare, Stockholms lan 1990 SLF Lakarjour AB, Stockholm, Sweden.

10 Salus, personal correspondence, Jan Pahlsson, General Manager, 11 June 1990.

11 Skandia, personal communication, Thomas Nysted, Product Development Office, 24 July 1990.

12 TryggHansa, personal communication, Karen Ericsson-Guta, Department Manager, 25 July 1990; WASA, personal communication, Bo Wickman, 6 August 1990.

13 Magnusson, M., Skandia Legal Department, personal conversation 15 June 1990, Stockholm, Sweden.

14 Svenska Dagbladet, Advertising Department, correspondence, June 1990. Special section, Tema: privatsjukvard, 9 April 1990; Experthjalp, 9 April 1990, 16 June 1990, 25 June 1990, 18 June 1990; Dagens Nyheter, phone conversation with Advertising Department, 17 July 1990, Stockholm, Sweden.

15 Privata Affarer, nr 6 June 1989; Ham, C., R. Robinson and M. Benzeval, Health Check: Health Care Reforms in an International Context, Kings Fund Institute, 1990.

16 OECD, 1987; SCB, 1988.

17 Swedish Press: Just a selection of examples of the extensive discussion of limits on health care spending are the following: Svenska Dagbladet, 26 January 1989, editorial page, Det viktigaste aterstar; Dagens Nyheter, 16 February 1989, Section 5a, 66 milj over budget; Kuriren, Orebro, 14 February 1989, Vi har rad med vard; Helsingborgs Dagblad, 2 February 1989, Ett vi har rad med vard; Helsingborgs Dagblad, 2 February 1989, Ett hot mot rattssakerheten. Similar articles could be found around the same time in Norrkoping, Goteborg, Skane, Orebro, Vaxjo, to name other places around the country.

18 Washington Post, Running out of gas: As a model, Sweden may have exhausted Itself, February 1990; International Herald Tribune, The 'Swedish model' is still alive, 27 June 1990.

19 Heclo, H., Policy and Politics in Sweden, Temple University Press, 1987.

20 Nationalrakenskaperna och LKELP, Sjukvardskostnadernas reala okning per ar, 1979-92.

21 Koer I Sjukvarden 2, Socialstyrelsen, 1989, pp. 22-23.

22 Landstingsforbundet and Statistiska Centralbyran, Nyfiken? Halso-och sjukvarden far ros och ris av allmanheten, Stockholm, Sweden, 1988.

23 Michels, R., Political Parties: A Sociological Study of the Oligarchy Tendencies of Modern Democracy, English version published in the USA, 1915.

24 90-Tals Programmet, en debattbok om arbetarrorelsens viktigaste fragor under 90-talet, Tidens Forlag, Stockholm, 1989.

25 Saltman, R. and von Otter, C., Revitalizing public health care systems: A proposal for public competition in Sweden, Health Policy (1987) 21-40.

26 Landstings Varlden, Vilken Vag Valjer Sjukvarden? pp. 10-11, 10/90.

27 Blomqvist, A., Swedish health care policy in international perspective, Stockholm School of Economics, 1989. 